\title{
BANTUAN TEKNIS DESAIN LANSEKAP AIR TERJUN KINAAPIAN DESA BATU KECAMATAN LIKUPANG SELATAN
}

\author{
Ingerid Lidia Moniaga \& Amanda Sutarni Sembel \\ Laboratorium Bentang Alam Program Studi Perencanaan Wilayah dan Kota, Fakultas Teknik, \\ Universitas Samratulangi (UNSRAT) \\ ingeridmoniaga73@gmail.com; amandasembel@gmail.com
}

\begin{abstract}
Desa Batu merupakan salah satu Desa yang berada di wilayah Kecamatan Likupang Selatan Kabupaten Minahasa Utara Provinsi Sulawesi Utara. Desa Batu memiliki kekayaan alam yang mempesona, salah satunya yakni air terjun Kina-apiaan yang terletak di kawasan agrowisata buah.Jarak tempuh lokasi air terjun dari desa berjarak $2 \mathrm{Km}$. Desa Batu merupakan desa yang memiliki potensi sumberdaya alam yang menarik dan berpeluang dikembangkan sebagai obyek wisata baru. Potensi air terjun desa Batu menjadi sumber air bagi desa-desa disekitarnya, yang walaupun musim kemarau panjang tidak mengalami penurunan debit air, tetapi tetap tersedia untuk mencukupi kebutuhan masyarakat Desa Batu dan desa sekitarnya.

Tujuan pelaksanaan kegiatan Pengabdian Kepada Masyarakat ini, yaitu memberi pembinaan dan pendampingan pada kelompok wisata desa Batu dalam Pengembangan Optimalisasi Ruang Luar atau Lanskap Air Terjun. Pembinaan dan pendampingan yang dilakukan untuk menangani beberapa masalah prioritas yang dilakukan dengan tahapan diantaranya : (1) Penyuluhan dan (2) Pelatihan.

Target luaran yang ingin dicapai pada pembinaan dan pendampingan masyarakat desa Batu adalah (1) meningkatnya pengetahuan masyarakat dalam Pengembangan Potensi Sumber Daya Alam yang bisa dikembangkan sebagai daya tarik obyek wisata alam melalui desain-desain ruang luar atau lanskap wisata, (2) memahami dan melakukan kegiatan praktek mengembangkan objek wisata alam, (3) memiliki kemampuan dalam mengelola lanskap wisata alam, (4) meningkatkan kualitas lingkungan desa, (5) menghasilkan artikel ilmiah yang dapat dipublikasikan pada seminar nasional.
\end{abstract}

Kata Kunci: optimalisasi ruang luar, lanskap air terjun, wisata alam.

\section{PENDAHULUAN}

\section{Analisis Situasi}

Desa Batu merupakan salah satu Desa yang berada di wilayah Kecamatan Likupang Selatan Kabupaten Minahasa Utara Provinsi Sulawesi Utara. Desa Batu memiliki kekayaan alam yang mempesona, salah satunya yakni air terjun Kina-apiaan. Air terjun ini ditemukan oleh hukum tua desa Batu pada tahun 2014 dan hasil musrembang desa, lokasi ini dijadikan sebagai salah satu obyek wisata di desa tersebut. Desa Batu yang berada di Kecamatan Likupang Selatan ini merupakan desa yang memiliki potensi sumberdaya alam yang menarik dan berpeluang dikembangkan sebagai obyek wisata baru di wilayah kecamatan Likupang Selatan. Hal tersebut karena pengembangan obyek wisata yang bersifat rekreatif belum tersedia di wilayah kecamatan Likupang Selatan. Optimalisasi ruang luar pada air terjun Kinaapian akan menciptakan daya tarik baru dalam memenuhi kebutuhan rekreasi dan bersantai di wilayah kecamatan Likupang Selatan sebagai wilayah yang terkecil di Kabupaten Minahasa Utara Provinsi Sulawesi Utara.

Potensi air terjun desa Batu menjadi sumber air bagi desa-desa disekitarnya, 
yang walaupun musim kemarau panjang tidak mengalami penurunan debit air, tetapi tetap tersedia untuk mencukupi kebutuhan masyarakat Desa Batu dan desa sekitarnya. Namun infrastruktur jalan sebagai aksesibilitas/pencapaian ke lokasi air terjun masih belum memadai. Jarak tempuh lokasi air terjun dari desa berjarak $2 \mathrm{Km}$. Keterbatasan sumber daya manusia serta dana dalam penataan lanskap wisata berskala kecamatan menjadi masalah berkembangnya objek wisata air terjun Kinaapian sebagai tempat rekreatif yang indah menarik dan representatif. Pengembangan lansekap atau ruang luar pada obyek air terjun Desa Batu diharapkan akan menjadi salah satu daya tarik bidang pariwisata kabupaten Minahasa Utara. Penataan lansekap obyek wisata air terjun Kinaapiaan desa Batu perlu mengembangkan komponenkomponen perancangan arsitektur lanskap diantaranya aplikasi lansekap yakni ruang parkir, soft material dan hard material. Sehingga bisa mencapai nilai-nilai keseimbangan, keselarasan, dan kehormonisan antara lingkungan alami dan lingkungan buatan. Hal ini penting dalam menunjang program pemerintah Kabupaten Minahasa Utara khususnya Dinas Pariwisata yang sedang mensosialisakan slogan, 'Mari Jo Pasiar Ka Minahasa Utara' (Mari Berjalanjalan Ke Minahasa Utara).

Tujuan kegiatan pengabdian di desa Batu yakni untuk mengoptimalkan kualitas lansekap / ruang luar pada obyek wisata air terjun Kinaapian Desa Batu melalui peran serta masyarakat dalam penciptaan kualitas lingkungan binaan yang selaras dengan lingkungan alami. Sehingga tujuan pemberdayaan masyarakat dalam partisipasi pembangunan obyek-obyek wisata menjadi model yang dapat diterapkan pada lokasilokasi wisata lain di wilayah Kabupaten Minahasa Utara. Kegiatan pengabdian ini menghasilkan bantuan teknis berupa desain-desain ruang luar yang memperhatikan penggunaan soft materal dan hard material sebagai elemen desain lanskap yang dapat menciptakan keindahan, daya tarik, dan pengalaman emosional dengan suasana rekreatif pada lokasi.

\section{Permasalahan Mitra}

Berdasarkan permasalahan di atas maka dapat dirumuskan masalah prioritas yang perlu ditangani oleh kelompok wisata desa Batu dan pendamping dari perguruan tinggi yaitu:

1. Tidak tersedianya sumber daya manusia (SDM) yang dapat mendesain ruang luar/lanskap wisata air terjun berproduk arsitektur lanskap;

2. Kurangnya pemahaman masyarakat akan pentingnya pengembangan potensi sumberdaya alam desa sebagai obyek rekreasi wisata alam yang dapat menunjang perekonomian desa;

3. Kurangnya pengetahuan masyarakat tentang pengembangan desain-desain lansekap air terjun yang tanggap terhadap lingkungan dan ekosistem alami; dan 
4. Kurangnya pengetahuan masyarakat dalam pembuatan lanskap obyek rekreasi wisata air terjun yang indah, bersih, dan menarik.

\section{Target dan Luaran}

Target luaran yang ingin dicapai pada pembinaan dan pendampingan kelompok wisata desa Batu Kecamatan Likupang Selatan Kabupaten Minahasa Utara adalah: 1) Menyediakan bantuan teknis DesainDesain Gambar Lanskap Air Terjun yang rekreatif; 2) Melakukan pendampingan optimalisasi ruang luar atau lanskap pada obyek air terjun Kinaapian; 3) Meningkatkan partisipasi masyarakat dalam penataan lansekap; dan 4) Menghasilkan artikel ilmiah yang dapat dipublikasikan pada seminar nasional. Jika kelompok wisata desa Batu berhasil menerapkan pengembangan dan pengelolaan yang melibatkan peran aktif masyarakat dalam penataan lanskap obyek wisata alam, maka kelompok masyarakat desa Batu ini diharapkan menjadi penggerak atau motivator bagi kelompok-kelompok masyarakat lainnya dalam pengembangan potensi-potensi desa sebagai area rekreasi guna menunjang pengembangan sektor pariwisata di Kabupaten Minahasa Utara.

\section{METODE PELAKSANAAN}

Berdasarkan permasalahan kelompok wisata desa Batu maka diperlukan pembinaan dan pendampingan terhadap kelompok tersebut. Pembinaan dan pendampingan yang dilakukan untuk menangani beberapa masalah prioritas yang dapat dilakukan dengan tahapan penyuluhan dan pelatihan.

\section{Penyuluhan}

Penyuluhan dilakukan terhadap anggota kelompok masyarakat dengan tujuan memperluas wawasan pengetahuan kelompok-kelompok tersebut, tentang konsep pengembangan obyek wisata alam dengan memahami prinsip-prinsip dan unsur-unsur desain dalam komponen perancangan lanskap. Materi penyuluhan menyangkut Perancangan Lanskap Obyek Wisata Air Terjun Desa Batu. Untuk kegiatan penyuluhan disiapkan brosurbrosur.

\section{Pelatihan}

Setelah dilakukan penyuluhan terhadap anggota kelompok masyarakat, selanjutnya dilakukan pelatihan bagi anggota kelompok masyarakat desa Batu. Pelatihan dimaksud adalah praktek penataan lanskap pada obyek rekreasi, sebagai berikut:

1. Penataan tata hijau dengan pemilihan jenis-jenis tanaman lanskap (soft material) yang mudah tumbuh dan adaptif pada ekosistem hutan lindung;

2. Penataan sirkulasi kendaraan dan pejalan kaki pada lokasi wisata alam sebagai aksesibilitas pada obyek yang dapat menciptakan kenyamanan bagi pengunjung; dan 
3. Penataan komponen-komponen lansekap atau (hard material) sebagai unsur pembentuk keindahan ruang luar.

\section{HASIL DAN PEMBAHASAN}

\section{Optimalisasi Ruang Luar Berdasarkan}

\section{Potensi Sumber Daya Alam}

Optimalisasi lanskap atau ruang luar pada obyek wisata air terjun 'Kinaapian' dilakukan dengan tahapan-tahapan diantaranya: a) survey dan observasi lapang untuk melihat langsung kondisi eksisting dan tapak air terjun Kinaapian; b) mengidentifikasi sirkulasi/pencapaian menuju lokasi, sumberdaya alam yang tersedia di sekitar lingkungan, area-area yang dapat dikembangkan dalam optimalisasi desain lanskap; dan c) inventarisasi elemen-elemen lanskap lingkungan sekitarnya.

Kondisi tapak air terjun 'Kinaapian' berada pada area berbukit dengan lingkungan alami yang masih terjaga dan terpelihara baik yaitu hutan yang berfungsi mengkonservasi air dan tanah. Sirkulasi dan pencapaian menuju air terjun 'Kinaapian' agak sulit karena harus melintasi sungai kecil yang berbatuan, pohon bambu yang rimbun, dan bukit-bukit pepohonan dengan ketinggian yang cukup terjal untuk mendaki sampai pada lokasi air terjun. Kesulitankesulitan tersebut disebabkan karena pemerintah baik dinas pariwisata maupun pemerintah desa belum mengembangkan infrastruktur dan fasilitas pendukung yang dapat menciptakan daya tarik wisata desa. Keberadaan inilah yang menjadi ketertarik- an bagi tim IbM untuk melaksanakan pengabdian kepada masyarakat melalui produk bantuan teknis desain lanskap air terjun 'Kinaapian' Desa Batu. Diharapkan melalui bantuan teknis desain pemerintah dan masyarakat dapat memahami, mengerti dan melakukan pengembangan obyek wisata guna mewujudkan visi desa di bidang pariwisata.

Perencanaan pengembangan obyek wisata alam air terjun Kinaapian Desa Batu Kecamatan Likupang Selatan kabupaten Minahasa Utara perlu melibatkan kelompok sadar pariwisata dan segenap lapisan masyarakat sebagai stakeholder dalam pengelolaan obyek wisata desa. Hal ini bertujuan agar supaya masyarakat terlibat langsung dalam upaya peningkatan ekonomi, kesejahteraan, peningkatan pelestarian sumberdaya alam sebagai penciptaan atraksi alam wisata di desa Batu.

Industri wisata alam dapat lestari dan berkesinambungan, bila atraksi alam tetap terpelihara kealamiahannya dan keutuhannya, sehingga kegiatan dan jenis wisata alam dapat terus diminati oleh wisatawan (Demartoto, A 2009). Bila atraksi alam mengalami kerusakan atau penurunan aspek alamiahnya, maka akan membuat wisatawan merasa tidak tertarik lagi dan mencari bentuk atraksi lain yang lebih membuat mereka terpuaskan. Kondisi ini dapat disikapi dengan menjaga atraksi alam agar tetap utuh dan berkesinambungan. Wisata alternatif berupa wisata alam dimaksudkan untuk dapat meningkatkan belanja wisatawan (expenditure) di 
daerah kunjungan. Peningkatan belanja wisatawan di daerah kunjungan inilah, yang seharusnya dapat meningkatkan pendapatan masyarakat di sekitar obyek wisata alam. Masyarakat lokal dapat membuka peluang usaha seperti usaha souvenir, usaha warung makanan. Di samping itu masyarakat lokal dapat memperoleh sebagian dari penjualan karcis tanda masuk (retribusi) ke lokasi obyek wisata alam.

\section{Optimalisasi Ruang Luar pada Obyek Air Terjun Kinaapian}

Penggunaan material atau bahan lansekap merupakan salah satu bagian yang penting dalam perancangan lansekap. Hal ini karena Lansekap pada dasarnya berkaitan erat dengan pembentukan ruang luar dan ruang terbuka. Pembentukan ruang sangat tergantung dari komponen pembentuk ruang. Komponen pembentukan ruang terdiri dari bidang alas, bidang dinding, dan bidang atap. Kualitas nilai ruang tergantung dari fungsi ruang yang diinginkan. Gubahan ruang luar terhadap fungsi ruang yang ingin dihasilkan dapat tergubah melalui bidangbidang sebagai komponen pembentuk ruang. Bidang yang dimaksud terbentuk karena adanya unsur material yang direkayasa sesuai bentuk, tekstur, warna, dan ukuran dimensi yang diciptakan (Hakim, R dan Utomo, H. 2008). Karena itu penguasaan dan pemahaman terhadap material atau bahan lansekap menjadi unsur penting dalam mendesain ruang luar. Dalam ilmu Arsitektur Lansekap dikenal dua bagian besar material lansekap yakni material lunak (soft materials) dan material keras (hard materials).

Arsitektur Lansekap dalam menggubah ruang dapat "menggubah ruang" dengan komponen material lunak, yaitu tanaman atau pepohonan dan air. Tanaman merupakan material lansekap yang hidup dan terus berkembang. Kualitas dan kuantitas ruang terbuka akan terus berkembang dan berubah sesuai dengan pertumbuhan tanaman. Dalam desain lansekap, tanaman sangat erat hubungannya dengan waktu dan perubahan karakteristik tanaman. Penggunaan material keras dalam desain lansekap terdiri atas lima bagian besar yaitu material keras alami, material keras alami dari potensi geologi, material keras buatan bahan metal, material keras buatan sintetis/tiruan, material keras buatan kombinasi.

Desain Lansekap Air Terjun Kinaapian menggunakan aplikasi desain soft material dan hard material. Penggunaan material lunak (soft material) diantaranya tanaman-tanaman yang tumbuh di sekitar lingkungan air terjun yang mudah tumbuh, toleran terhadap lingkungan sekitar, dan menciptakan efek visual yang berimbang dengan lingkungan Air Terjun Kinaapian. Demikian halnya dengan penggunaan material keras (hard material) menggunakan material alami yang banyak tersedia di lingkungan sekitarnya yakni material bambu. Bambu merupakan material alami yang dapat dipergunakan dalam desain ruang 
luar yang dapat menciptakan kesan dan nuansa pedesaan yang hijau dan asri.

\section{KESIMPULAN}

Aplikasi desain lansekap pada air terjun Kinaapian diwujudkan pada konsep sirkulasi, tata hijau, efek visual, nilai estetika, dan fasilitas parkir. Sirkulasi merupakan suatu lintasan pergerakan yang harus didesain dengan baik sesuai kondisi tapak dan lokasi air terjun Kinaapian. Sebagaimana telah dijelaskan pada bagian sebelumnya bahwa lokasi menuju air terjun agak sulit karena harus melintasi sungai kecil yang berbatuan, pohon bambu yang rimbun, dan bukit-bukit pepohonan dengan ketinggian yang cukup terjal. Maka penyelesaian desain sirkulasi yakni dengan menciptakan bentuk lintasan pergerakan yang mengelilingi tapak air terjun dengan lintasan satu arah pergerakan manusia. Jenis pergerakan menciptakan suasana emosional yang bervariasi diantaranya suasana pergerakan menurun, terlindungi, dan pergerakan mendaki menaiki anak tangga dengan tekstur bahan alami bambu. Selanjutnya konsep tata hijau di desain sesuai kondisi lingkungan sekitar yang masih alami dan bernuansa hutan.

Tanaman-tanaman yang dikembangkan pada desain air terjun Kinaapian yaitu yang toleran dan sesuai dengan fungsi tanaman tersebut diantaranya Bambu (Bambusa arundinacea), Hanjuang (Cordylin sp.), Puring (Codeaum variegatum), Philodendron (Araceae), Seruni (Wedelia 6 montana), Iris (Neomarica longifolia), Bunga kancing (Gomphrena globosa), Bunga pukul empat (Mirabilis jalapa). Penempatan komposisi dan perletakan tanamantanaman sebagai tata hijau menciptakan efek visual dalam desain lansekap air terjun Kinaapian. Sehingga harmonisasi alami dan keseimbangan lingkungan buatan dapat tercapai dalam mewujudkan desain lansekap yang memiliki nilai estetika, ramah lingkungan, dan berkelanjutan.

Fasilitas parkir merupakan komponen desain yang harus disediakan pada lokasi-lokasi tempat wisata dan rekreasi seperti air terjun Kinaapian. Kebutuhan akan tempat parkir dalam suatu desain lansekap merupakan bagian dari prasarana lingkungan yang harus tersedia. Lokasi parkir pada obyek rekreasi air terjun Kinaapian memang sangat terbatas pada ukuran lahan yang ada. Namun demikian, pemerintah perlu mengadakannya melalui pengembanagan lahan sekitar lingkungan air terjun. Parkir adalah tempat pemberhentian kendaraan dalam jangka waktu yang lama atau sebentar tergantung pada kendaraan dan kebutuhannya. Penempatan parkir didesain tidak terlalu jauh dari pusat kegiatan air terjun. Bahan atau material lansekap menggunakan material paving yang berfungsi menyerap air permukaan seperti air hujan dengan penempatan pohon-pohon peneduh di sekitar area parkir sehingga berkesan sejuk. 


\section{KEPUSTAKAAN}

Moniaga, I. 2016. Pengembangan Rancangan Lanskap Air Terjun Tunan Desa Talawaan Kabupaten Minahasa Utara Provinsi Sulawesi Utara. Lembaga Penelitian dan Pemberdayaan Masyarakat (LPPM) Unmas Denpasar JL. Kamboja No. 11 A Kota Denpasar Provinsi Bali 29 - 30 AGUSTUS 2016, 607-616

Demartoto, A. 2009. Partisipasi Masyarakat Dalam Pengelolaan Wisata Alam Air Terjun Jumog, Desa Berjo, Kecamatan Ngargoyoso, Kabupaten Karang Anyar
Provinsi Jawa Tengah [Laporan Penelitian]. Universitas Sebelas Maret Surakarta.

Hakim, R dan Utomo, H. 2008. Komponen Perancangan Arsitektur Lansekap, Prinsip-Unsur dan Aplikasi Desain. Bumi Aksara. 242 hal.

Pradana, L.B dkk. Pelatihan Manajemen Keuangan Untuk Masyarakat di Desa Wisata Kabupaten Bogor [Laporan Pengabdian Kepada Masyarakat]. 2016. Sekolah Tinggi Ilmu Ekonomi Wiyatamandala. 
Jurnal ABDIMAS, Vol. 11, No. 1, April 2018

ISSN: 1979-0953 | e-ISSN: 2598-6066 